\title{
Biosorption of 2,4 dichlorophenol Onto Turkish Sweetgum Bark in a Batch System: Equilibrium and Kinetic Study
}

\author{
Dilek Ylldız, ${ }^{1} *$ Feyyaz Keskin ${ }^{1}$ and Ahmet Demirak ${ }^{2}$ \\ ${ }^{1}$ Mugla Sitkı Kocman University, Research and Application Centre For Research Laboratories, 48000 Mugla, Turkey \\ ${ }^{2}$ Mugla Sitkı Kocman University, Department of Chemistry, 48000 Mugla, Turkey \\ * Corresponding author: E-mail: dilekyildiz2003@ hotmail.com \\ Tel: +9002522111675
}

Received: 09-12-2016

\begin{abstract}
In this study, Turkish Sweetgum bark was used as a new biosorbent to investigate the removal of hazardous 2,4 dichlorophenol (2,4-DCP) from aqueous solutions in batch biosoption experiments. The effective usage of Turkish sweetgum bark is a meaningful work for environmental utilization of agricultural residues. The effects of experimental parameters like solution $\mathrm{pH}$, contact time, initial concentration of adsorbate and amount of bisorbent dosage were investigated in a series of batch studies at $25^{\circ} \mathrm{C}$. Taguchi's Orthogonal Array (OA) analysis was used to find the best experimental parameters for the optimum design process in this study. The functional groups and surface properties of biosorbent were characterized by using Fourier transformer infrared (FTIR) and scanning electron microscopy (SEM) techniques. The experimental data were fitted to Langmuir isotherm and Freundlich isotherm models. There is a good agreement between the parameters and this confirms the monolayer adsorption of 2,4-DCP onto sweetgum bark. As a result of kinetic studies, the pseudo-second-order kinetic model was found to be suitable for all the data. Also, the results of the study show that Turkish Sweetgum bark can be potential as a low-cost alternative commercial adsorbents for removal 2,4 dichlorophenol from aqueous solutions.
\end{abstract}

Keywords: 2,4 dichlorophenol; Biosorption; Turkish Sweetgum; Equilibrium; Kinetics; Taguchi’s Orthogonal Array

\section{Introduction}

One type of dangerous wastes that are chiefly produced during chemical and many other industrial and agricultural activities is phenols and phenol compounds. ${ }^{1-6}$ If the low concentrations of pollutants are harmful to organism, these pollutants are considered as priority pollutants. Many of them have potential to harm human health; therefore, they have been classified as hazardous pollutants. ${ }^{7}$ United State Environmental Protection Agency (USEPA) has registered phenolic compounds as priority pollutants. Most of the phenolic compounds are toxic and hardly biodegradable, and it can be really difficult to get rid of them in the environment. Especially chlorophenols (CPs) are believed to create bad taste and odor in drinking water at concentrations below $0.1 \mathrm{~g} / \mathrm{L}$ and cause adverse impacts on the environment. ${ }^{8}$
Some physicochemical and biological methods including adsorption, extraction by chemical solvents, air stripping, freezing and crystallization, chemical oxidation, wet oxidation, advanced oxidation processes, biological degradation biosorption, coagulation, chlorination and liquid membrane permeation have been developed for the removal of phenolic compounds from aqueous solutions. ${ }^{6,7,9,10-13}$ Among these methods, the ones used for the concentration of the chlorinated phenols on the solid phase are adsorption and ion exchange methods but they are not for complete mineralization. The ones used for complete mineralization and combination of chlorophenols are chemical or biological oxidation methods. While one advantage of chemical oxidation methods is their being fast, they might result in undesirable by-products and they are expensive. Mostly preprocessed and rigid solid bisorbent material was investigated for removal hazardous wastes from aqueous solutions. Pretreatment is certainly advantageous 
concerning mechanical properties, but it is needed additional resources. Therefore, naturally immobilized biomass in the form of pellets with good biosorption capacities is a type of biosorbent. However, it is a highly porous, soft and mechanically sensitive material, and this might affect the column performance. ${ }^{14}$ Biosorption of chlorophenols are more specific and relatively cheap than chemical oxidation methods. Biosorption methods of chlorophenols were also investigated by many researchers. ${ }^{7-10}$ According to recent studies, some natural minerals, industrial wastes, agricultural wastes, and forest wastes are low-cost adsorbent materials. ${ }^{15-18}$ Agricultural wastes among them are one of the most promising groups of adsorbent materials.

New adsorbents that are locally-easily available, high adsorption capacity and economic materials, or certain waste products from industrial or agricultural operations, may have potential as low-cost sorbents. ${ }^{19-21}$ Their unique chemical composition makes these wastes economic and ecofriendly alternatives the removal of chlorophenols. ${ }^{6,7,22,23}$ We are interested in bark of Turkish Sweetgum as biosorbent. The sweetgum, which is widely known as Turkish sweetgum. is a deciduous tree native to the eastern Mediterranean region Styrax liquidus obtained from sweetgum have been known since very old times and they are known to have been used to mummify pharoses in ancient Egypt . The volatile oil extracted from Styrax liquidus has been utilized for the production of pharmaceutical and cosmetic products and they are made available in Turkey through export. ${ }^{24}$ The barks of sweetgum are a forest wastes to obtain the export goods from sweetgum plant and Styrax liquidus. Processed Turkish sweetgum barks are left in the forest as waste. These can cause forest fires. So it should be cleaned from the forest. Sweetgum bark consists of tannin compounds. Previous studies have reviewed low-cost adsorbents including bark/tannin, lignin, chitin/chitosan, non-living biomass etc. ${ }^{19}$ There are main objective of the present study is to explore the ability of sweetgum (Turkish Sweetgum) bark that become forest waste to remove 2,4-DCP from aqueous solutions. For this reason, biosorbent was characterized using Fourier transformer infrared spectroscopy (FTIR) and Scanning Electron Microscopy (SEM). In addition, experimental parameters such as solution $\mathrm{pH}$, contact time, initial concentration of adsorbate and amount of biosorbent dosage were investigated. A statistical optimization was used to determine the optimum biosorption conditions for removal of 2,4-DCP from aqueous solutions in sweetgum bark. Moreover, adsorption isotherm models and kinetics models were studied to understand the biosorption mechanism for theoretical evaluation.

\section{Materials and Methods}

\section{1. Materials}

The bark of sweetgum was obtained from the Mugla Manager ship of Governmental Operation of Forestry, Ge- neral Directorate of Forestry, Ministry of Environment and Forestry, Republic of Turkey at November, 2015. The 2,4 dichlorophenol, > 99\%, (2,4-DCP) was from SigmaAldrich (St. Louis, MO, USA). 4-aminoantipyrine and potassium ferricyanid used in this study were obtained from Merck and were of GR grade.

\section{2. Equipment and Analysis}

A pH meter (WTW) was used for the measurement of $\mathrm{pH}$. The concentrations of phenol compound were analyzed calorimetrically by using 4-aminoantipyrine and potassium ferriciyanid at $\mathrm{pH} 7.9 \pm 0.1$ according to the Standard Methods. ${ }^{25}$ All the analyses of this study were performed in the laboratory that has a framework of ISO IEC 17025 Laboratory accreditation

\section{3. Biosorbent}

The sweetgum consists of resin alcohols avaiblable free and combined with cinnamic acid, which makes up $30-45 \%$ of the total weight. Detailed chemical composition of TSB was styrene (1.56); a-pinene (1.02); benzaldehyde (0.47); b-pinene (0.15); benzyl alcohol (1.22); acetophenone (0.19); 1-phenyl-1-ethanol (0.17); hydrocinnamyl alcohol (41.13); trans-cinnamyl aldehyde (0.24); trans-cinnamyl alcohol (45.07) and bcaryophyllene $(3.60 \%) .{ }^{26}$ The barks of sweetgum were dried in the oven at $60{ }^{\circ} \mathrm{C}$ for $48 \mathrm{~h}$ and then passed through a $150 \mu \mathrm{m}$ size screen to use it in the study.

\section{4. Preparation of Synthetic Sample}

It was prepared for a stock solution of 2,4-DCP (1000 mg/l) with distilled water. To obtain all the solutions of varying concentrations, the stock solution was used in the current study. The $\mathrm{pH}$ of each solution was adjusted to the desired value using $0.1 \mathrm{M} \mathrm{HCl}$ and $0.1 \mathrm{M}$ $\mathrm{NaOH}$.

\section{5. Batch Sorption Experiments}

The batch technique was used to conduct the experiments of sorption in a routine manner. The dry biomass $(1,0 \mathrm{~g})$ was shaken with $50 \mathrm{ml}$ of $2,4-\mathrm{DCP}$ solution at a concentration of $150 \mathrm{mg} / \mathrm{l}$ in a shaker at room temperature $\left(20 \pm 0.5^{\circ} \mathrm{C}\right)$ for about 150 minutes. For the separation of the particles of sweetgum barks by filtration, a $0.45 \mu \mathrm{m}$ membrane filter was used. The amounts of sweetgum barks adsorbed in each case were measured by calculating the difference between the initial and the final concentrations of 2,4-DCP.

By using the difference between the initial concentration and equilibrium (qe) of 2,4-DCP concentration, biosorption capacity at equilibrium time (qe) was calculated as follows: 


$$
\mathrm{qe}=V(\mathrm{Co}-\mathrm{Ce}) / \mathrm{M}
$$

where $\mathrm{V}$ is the sample volume (L), Co is the initial concentration of 2,4-DCP $(\mathrm{mg} / \mathrm{l})$, Ce is the equilibrium or final concentration of 2,4-DCP $(\mathrm{mg} / \mathrm{l}), \mathrm{M}$ is the dry weight of ( $0.5 \mathrm{~g}$ for this study), and qe is the biomass biosorption capacity of the biomass at equilibrium time.

\section{6. Optimization Study}

Taguchi is a simple and effective statistical method, which organizes a systematic experimentation to determine the near to optimum settings of design parameters for performance, quality, and cost. In this method, a large number of variables are studied with a small number of experiments using orthogonal arrays. ${ }^{27-32}$ For this reason this study was carried out using Taguchi statistical method.

In the Taguchi approach, an orthogonal arrays and analysis of variance (ANOVA) are used for the analysis of experimentations. By using ANOVA, the effect of factors can be estimated and by orthogonal arrays the minimum number of experiments is needed. In this method variability of parameters is expressed by signal-to-noise $(\mathrm{S} / \mathrm{N})$ ratio, which represents the ratio of desirable results (signal) to undesirable results (noise). In this statistical method the $\mathrm{S} / \mathrm{N}$ ratio is used to measure the quality characteristic derivation from the desired value. The maximum $\mathrm{S} / \mathrm{N}$ ratio is considered as the optimal condition as the variability is inversely proportional to the $\mathrm{S} / \mathrm{N}$ ratio. ${ }^{33}$

The Taguchi experimental design method was used to determine optimum removal conditions. The effect of experimental parameters such as $\mathrm{pH}$, amount of biosorbent, initial concentration of adsorbate and contact time were investigated using an L25 $\left(5^{5}\right)$ orthogonal array. One of the main objectives of this research was to apply Taguchi statistical approach to optimize the reaction parameters toward higher adsorption efficiency.

In this work, the effect of four important factors including $\mathrm{pH}$, amount of biosorbent, initial concentration of adsorbate, contact time and each factor at five levels on the adsorption efficiency of 2,4- DCP were studied using Taguchi's method. The used level setting values of the main factors (A-D) and the L25 (55) matrix employed to

Table 1. Factors and levels for experimental parameters used to in sorption capacity test

\begin{tabular}{ccccc}
\hline Levels & $\begin{array}{c}\mathbf{A} \\
(\mathbf{p H})\end{array}$ & $\begin{array}{c}\text { B (amount } \\
\text { of biosorbent } \\
(\mathbf{g})\end{array}$ & $\begin{array}{c}\text { C (initial } \\
\text { concentration } \\
\text { of adsorbate } \\
\text { (mg/L) }\end{array}$ & $\begin{array}{c}\text { D (contact } \\
\text { time (min) }\end{array}$ \\
\hline 1 & 2 & 0,2 & 25 & 30 \\
2 & 4 & 0,4 & 50 & 60 \\
3 & 6 & 0,6 & 100 & 90 \\
4 & 8 & 0,8 & 150 & 120 \\
5 & 10 & 1,0 & 200 & 150 \\
\hline
\end{tabular}

Table 2. L25 Experimental and expected results from Taguchi's Orthogonal Array (OA) analysis

\begin{tabular}{ccccc}
\hline $\begin{array}{c}\text { Experiment } \\
\text { no. }\end{array}$ & pH & $\begin{array}{c}\text { Amount } \\
\text { of } \\
\text { biosorbent }\end{array}$ & $\begin{array}{c}\text { Initial } \\
\text { concentration } \\
\text { of adsorbate }\end{array}$ & $\begin{array}{c}\text { Contact } \\
\text { time }\end{array}$ \\
\hline 1. & 1 & 1 & 1 & 1 \\
2. & 1 & 2 & 2 & 2 \\
3. & 1 & 3 & 3 & 3 \\
4. & 1 & 4 & 4 & 4 \\
5. & 1 & 5 & 5 & 5 \\
6. & 2 & 1 & 2 & 3 \\
7. & 2 & 2 & 3 & 4 \\
9. & 2 & 3 & 4 & 5 \\
10. & 2 & 4 & 5 & 1 \\
11. & 2 & 5 & 1 & 2 \\
12. & 3 & 1 & 3 & 5 \\
13. & 3 & 2 & 4 & 1 \\
14. & 3 & 3 & 5 & 2 \\
15. & 3 & 4 & 1 & 3 \\
16. & 3 & 5 & 2 & 4 \\
17. & 4 & 1 & 4 & 2 \\
18. & 4 & 2 & 5 & 3 \\
19. & 4 & 3 & 1 & 4 \\
20. & 4 & 4 & 2 & 5 \\
21. & 4 & 5 & 3 & 1 \\
22. & 5 & 1 & 5 & 4 \\
23. & 5 & 2 & 1 & 5 \\
24. & 5 & 3 & 2 & 1 \\
25. & 5 & 4 & 3 & 2 \\
26. & 5 & 5 & & 3 \\
\hline & & 5 & 5 & \\
\hline
\end{tabular}

assign the considered factors are shown in Tables $\mathbf{1}$ and $\mathbf{2 ,}$ respectively.

The experimental data were analyzed using the statistical software MINITAB 15 . The data $\left(y_{\mathrm{i}}\right)$ and corresponding S/N ratios were calculated on the basis of Taguchi's "larger is better" approach.

\section{7. Scanning Electron Microscopy}

Scanning Electron Microscopy with Energy Dispersive Spectroscopy (SEM-EDS) was used to characterize the structures of the samples (JEOL SEM 7700F) in the Research Centre Laboratory at Mugla Sitkı Koçman University (Turkey).

\section{8. FTIR Analysis}

FTIR spectrum of the samples were performed in Perkin Elmer Each spectrum was recorded in a frequency of $400-4000 \mathrm{~cm}^{-1}$ using potassium bromide $(\mathrm{KBr})$ disc. The $\mathrm{KBr}$ was oven-dired to minimize the interference of water.

\subsection{The Determination of $\mathrm{pHpzc}$}

Batch equilibrium experiments were used to estimate zero point charge (pHpzc). $50 \mathrm{~mL}$ of $0.01 \mathrm{M} \mathrm{NaCl}$ solu- 
tion was poured into several erlenmeyer flasks. The $\mathrm{pH}$ of solution for each flask was adjusted to a value between 2 and 12 by addition of $0.1 \mathrm{M} \mathrm{HCl}$ or $0.1 \mathrm{M} \mathrm{NaOH}$ solution. Then, $0.10 \mathrm{~g}$ of adsorbent was added to the flasks and the dispersion was stirred for $48 \mathrm{~h}$. After this time the final p$\mathrm{H}$ was measured.A plot of the final $\mathrm{pHf}$ as a function of the initial pHi provides pHpzc of the adsorbents by the plateau of constant $\mathrm{pH}$ to the ordinate. ${ }^{34}$

\section{Results and Discussion}

\section{1. Optimization Study}

As the orthogonal array experimental design method was found to be the most appropriate for the conditions under investigation, it was chosen to determine the experimental plan, L25 $\left(5^{5}\right)$ (Table 2); four parameters each with five values. The data (yi) and corresponding $\mathrm{S} / \mathrm{N}$ ratios were calculated on the basis of Taguchi's "larger is better" approach using Eq. 2

$$
\mathrm{S} / \mathrm{N} \text { Oran } 1=-10 \cdot \log \left[\sum(1 / \mathrm{Y} 2) / \mathrm{n}\right]
$$

In order to calculate the effects of parameters, $\mathrm{S} / \mathrm{N}$ ratio was averaged for each level. The effect of the noise sources on the adsorption process was observed by repeating each experiment twice under the same conditions. The sequence, in which the experiments were carried out, was randomized to avoid any personal or subjective bias.
In the proposed method, no interaction between the variables was found in the matrix and the focus was placed on the main effects of the four most important factors. The optimum design for the adsorption of 2,4-DCP by Sweetgum bark is an important aspect in the production of the adsorption process. It can be concluded that the values of optimum experimental parameters for adsorption capacity of 2,4-DCP are as below: contact time (150 $\mathrm{min}$ ), amount biosorbent (1 g), initial concentration of adsorbate (150 $\mathrm{mg} / \mathrm{L}$ ) and $\mathrm{pH}(2)$ (figure1).

Taguchi method predicted that the adsorption efficiency under the optimum conditions will be $90.2371 \%$. Under these optimum conditions, it was determined that the 2,4- DCP adsorption efficiency was $89.2158 \%$.

\section{2. Influence of $\mathrm{pH}$}

The previous studies have shown that $\mathrm{pH}$ of the solution is a critical parameter affecting biosorption of 2,4$\mathrm{DCP}^{7,12,35}$ The $\mathrm{pH}$ ranges of $2-10$ were used in this study to ensure the presence of the protonated form of 2,4-DCP and the increase of negative charges at the surface of the particles of bark of sweetgum. The initial $\mathrm{pH}$ of the solution was increased with the decrease in the adsorption capacity of 2,4-DCP (figure 2). The figure shows that maximum adsorption capacity of 2,4-DCP was observed at a $\mathrm{p}$ $\mathrm{H}$ of 2.0. Also it was found the same values of initial $\mathrm{pH}$ of the solution using Taguchi's Orthogonal Array (OA) analysis (figure 1).

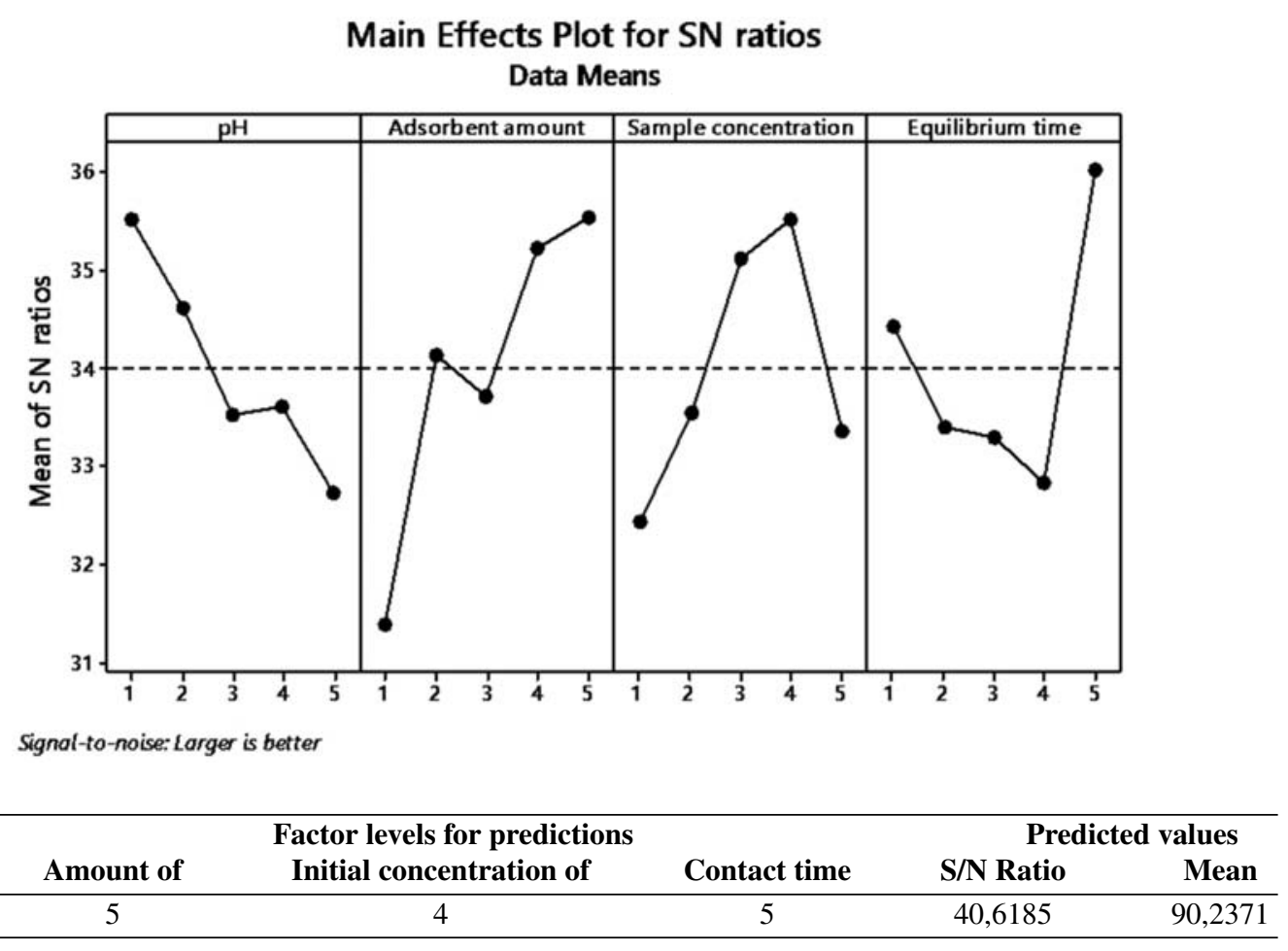

Figure 1. Main effects plot for SN ratios, Factor levels for predictions, Predicted values 


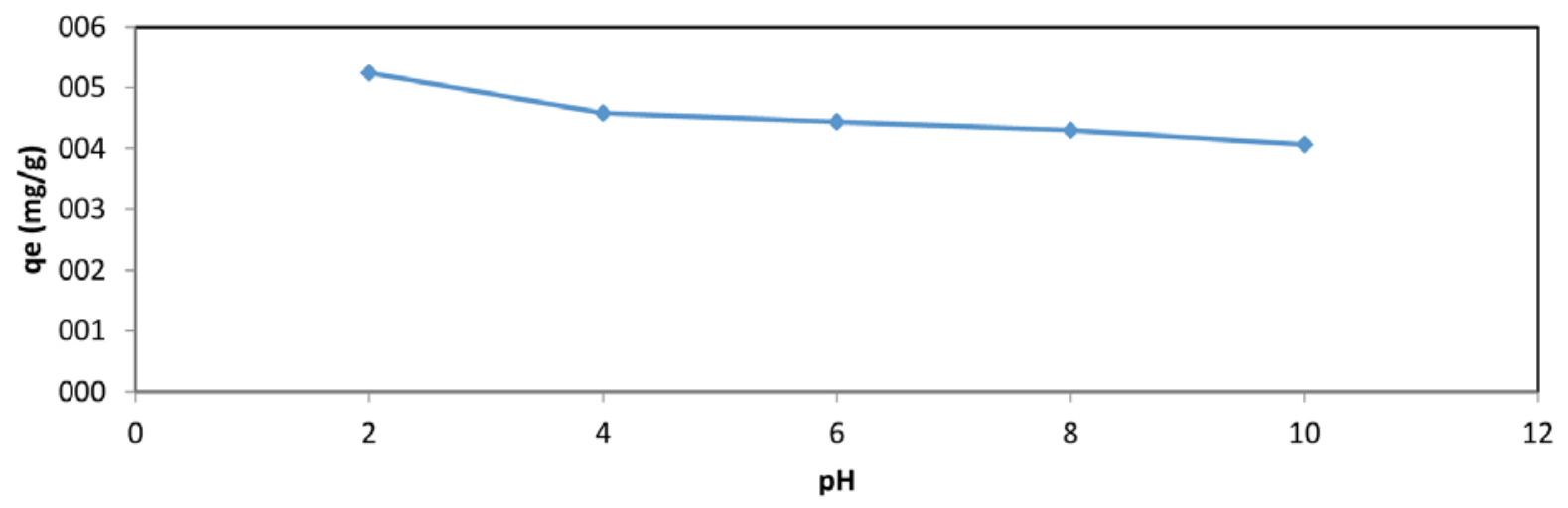

Figure 2.The effect of $\mathrm{pH}$ on the equilibrium sorption capacities of sweetgum bark, for 2,4-DCP

The Henderson-Hasselbalch equation $(\mathrm{pH}=p K a+\log [A-] /[A H])$ is useful for estimating the $\mathrm{pH}$ of acidic compounds, such as 2.4-DCP. The value of $\mathrm{p}-$ $\mathrm{Ka}$ for 2,4-DCP which is known to be weak acid is 7.85 . The value of $\mathrm{pH}(2)$ is lower than $\mathrm{pKa}$ (7.85), the dissociation degree of 2,4-DCP to form anions increases. The sweetgum bark consists of hydrolyzable tannin compounds. ${ }^{36}$ The hydroxyl groups of the carbohydrate in hydrolyzable tannin compounds provide negative charge in surface of the biomass as the $\mathrm{pH}$ increases. Consequently, the electrostatic impulse between the identical charged target molecules decreases the adsorption capacity of 2,4-DCP in increasing $\mathrm{pH}$ of the 2,4-DCP in aqueous solution.

\section{3. Effect of Contact Time and Initial Concentration}

The relationship between contact time and 2,4DCP sorption on sweetgum bark at different initial 2,4-
DCP concentrations is presented in Figure 3. The rate of sorption capacities increased slightly at contact time of $150 \mathrm{~min}$. The sorption was not very rapid and the equilibrium time for 2,4-DCP calculated from this study is more than what is reported for phenols onto different biomass. ${ }^{1}$ The initial concentration of aqueous solution ensures an important locomotive strength to accomplish all mass transfer resistances of adsorbate between the aqueous solid phase and therefore increases the rate of adsorbate molecules passing from the solution to the adsorbent surface. ${ }^{1,37-39}$ Accordingly, a low initial concentration of 2,4-DCP would decrease the process of adsorption (Figure 3). Also Taguchi's Orthogonal Array (OA) analysis indicates that the optimum of equilibrium time and initial concentration of 2,4DCP in this study are $150 \mathrm{~min}$ and $150 \mathrm{mg} / \mathrm{L}$, respectively (Figure 1).

\section{4. Adsorption Kinetic Models}

The pseudo - first-order model and the pseudo - second-order model were performed to the experimental pa-

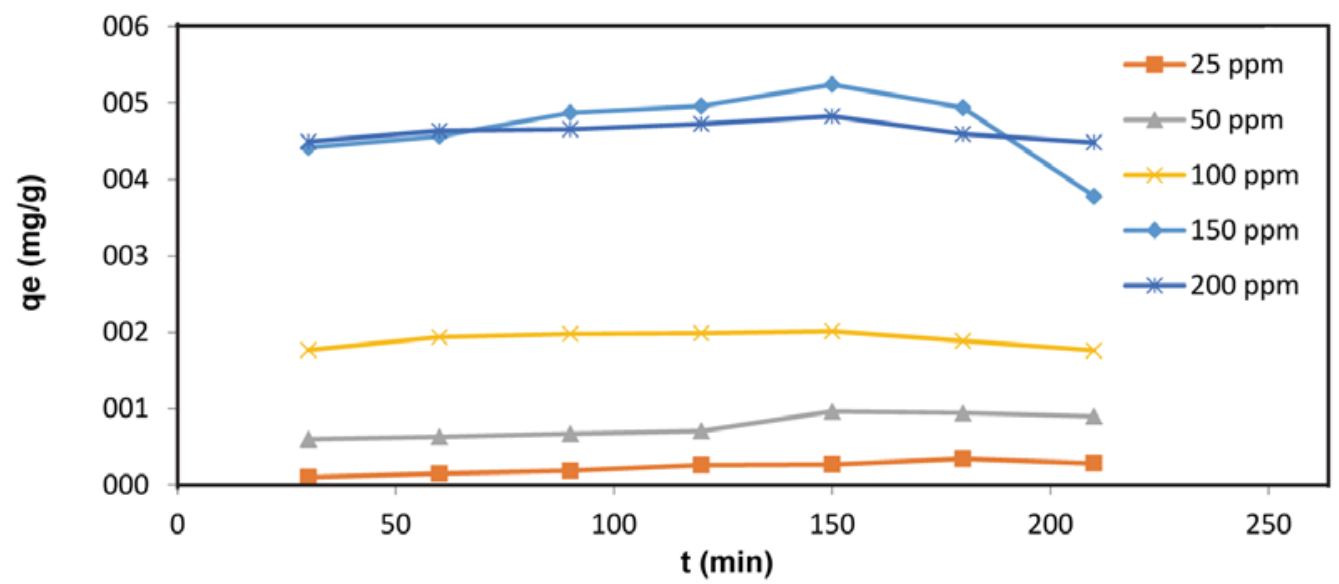

Figure 3. The sorption equilibration time of 2,4-DCP by dried sweetgum bark (biomass: $1 \mathrm{~g}, 2$,4-DCP concentration: 25, 50, 100, 150, 200 mg/I: temperature $20 \pm 0.5$, agitation rate: $125 \mathrm{rpm}$ ) 
rameters to evaluate the adsorption kinetics of 2,4-DCP onto sweetgum bark in this study.

\section{4. 1. Pseudo-first-order Model and Pseudo-second-order Model}

The kinetic of biosorption by any biological material in an aqueous solution has been tested for the pseudofirst-order model equation given by Lagergren. The pseudo-second-order model may provide a better description of the adsorption kinetics. ${ }^{7,22}$

The pseud-first-order Lagergren equation is:

$$
\log (q e-q t)=\log q e c a l-(K 1 / 2,303) t
$$

where qe and qt are the amount of 2,4-DCP adsorbed per unit of biomass $(\mathrm{mg} / \mathrm{g})$ at equilibrium and at time $\mathrm{t}, \mathrm{t}$ is the contact time ( $\mathrm{min}$ ) and $\mathrm{k}_{1}$ is the rate constant of this equation $(1 / \mathrm{min})$. The values of $\mathrm{K}_{1}$ and $\mathrm{q}_{\mathrm{ecal}}$ were calculated from a plot of $\log$ (qe-qt) versus $t$.

The pseudo-second-order kinetic equation is ${ }^{22,39}$

$$
{ }^{t} / q t^{=1} / K_{2} \cdot q_{\text {ecal }}^{2}+{ }^{t} / q_{\text {ecal }} \quad \mathrm{h}=K_{2} q_{\text {ecal }}^{2}
$$

where $\mathrm{h}$ represents the initial adsorption rate $(\mathrm{mg} / \mathrm{g} \mathrm{min})$, and $\mathrm{K}_{2}$ is the rate constant in the pseudo-second-order kinetic model ( $\mathrm{g} / \mathrm{mg}$.min). The values of $\mathrm{q}_{\text {ecal }}, \mathrm{K}_{2}$ and $\mathrm{h}$ can be obtained by a linear plot of $t / q t$ versus $t$.

The linear regression correlation coefficient $\left(\mathrm{R}^{2}\right)$ values for Lagergren-first order kinetic model ranged from 0.8140 to 0.9922 , which was lower than the $\mathrm{R}^{2}$ values for Pseudo-second order kinetic model which ranged from 0.8140 to 0.9999 (Table 3). The reaction involved in present biosorption system may not be of the Lagergren first-order kinetic model. The whole range of data might not be sufficiently described by the Lagergren-first order kinetics. Moreover, the $\mathrm{q}_{\text {ecal }}$ values for pseudo-second-order kinetic model were closer to the experimental qe values than the calculated $\mathrm{q}_{\mathrm{ecal}}$ values for Lagergren -frist-order kinetic model and, also, calculated $\mathrm{q}_{\mathrm{ecal}}$ values agreed with experimental qe values for pseudo-second-order kinetic (Table 3). These values show that pseudo-second-order kinetic fits for the biosorption of 2,4- DCP on the sweetgum bark. The Pseudo-second-order kinetic model was suitable for all the data. The process of the Pseudofirst-order kinetic model has been used for adsorption of reversible with an equilibrium being established between

Table 3. Parameters of Lagergren-first order kinetic model Pseudo-second order kinetic model for 2,4- DCP adsorption onto sweetgum bark (pH:

\begin{tabular}{|c|c|c|c|c|c|c|c|}
\hline \multirow{2}{*}{$\begin{array}{l}\mathrm{mg} / \mathrm{L}) \\
2,4 \text { DCP }\end{array}$} & \multicolumn{3}{|c|}{ Lagergren-first order kinetic model } & \multirow[b]{2}{*}{$\mathbf{R}^{2}$} & \multicolumn{3}{|c|}{ Pseudo-second order kinetic model } \\
\hline & $q_{e}(\mathrm{mg} / \mathrm{g})$ & $\mathrm{K}_{1}\left(\min ^{-1}\right)$ & $\mathbf{q}_{\text {ecal }}(\mathrm{mg} / \mathrm{g})$ & & $\mathrm{q}_{\mathrm{eca}} \mathrm{l}(\mathrm{mg} / \mathrm{g})$ & $\mathrm{K}_{2}\left(\mathrm{gmg}^{-1}\right)$ & $\mathbf{R}^{2}$ \\
\hline 25 & 0,269 & 1,74 & 0,029 & 0,8124 & 0,514 & 0,0187 & 0,814 \\
\hline 50 & 0,963 & 2,43 & 0,004 & 0,9922 & 1,049 & 0,0257 & 0,8619 \\
\hline 100 & 2,013 & 1,74 & 0,029 & 0,8124 & 2,077 & 0,0984 & 0,9999 \\
\hline 150 & 5,243 & 1,28 & 0,013 & 0,9609 & 5,482 & 0,0182 & 0,9967 \\
\hline 200 & 4,828 & 2,16 & 0,012 & 0,9483 & 4,900 & 0,0584 & 0,9995 \\
\hline
\end{tabular}
2 ; biomass: $1 \mathrm{~g}$, temperature $20 \pm 0.5$, agitation rate: $125 \mathrm{rpm}$ )

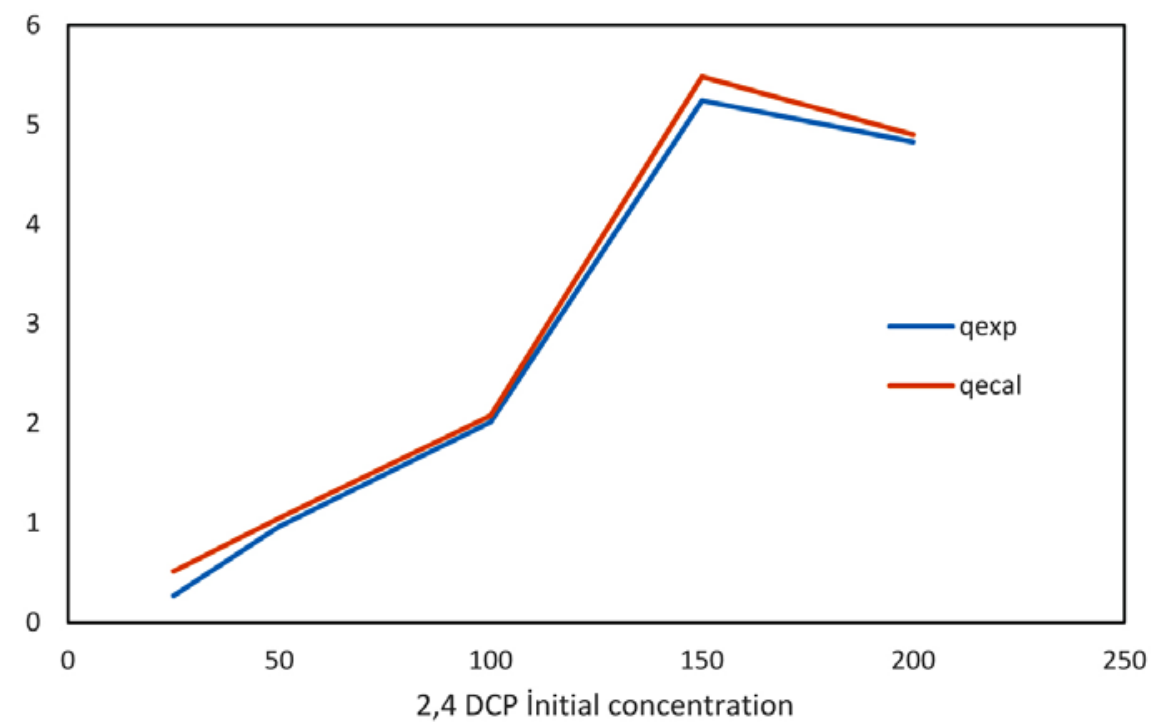

Figure 4. Graphical representation of Pseudo-second order kinetic model 


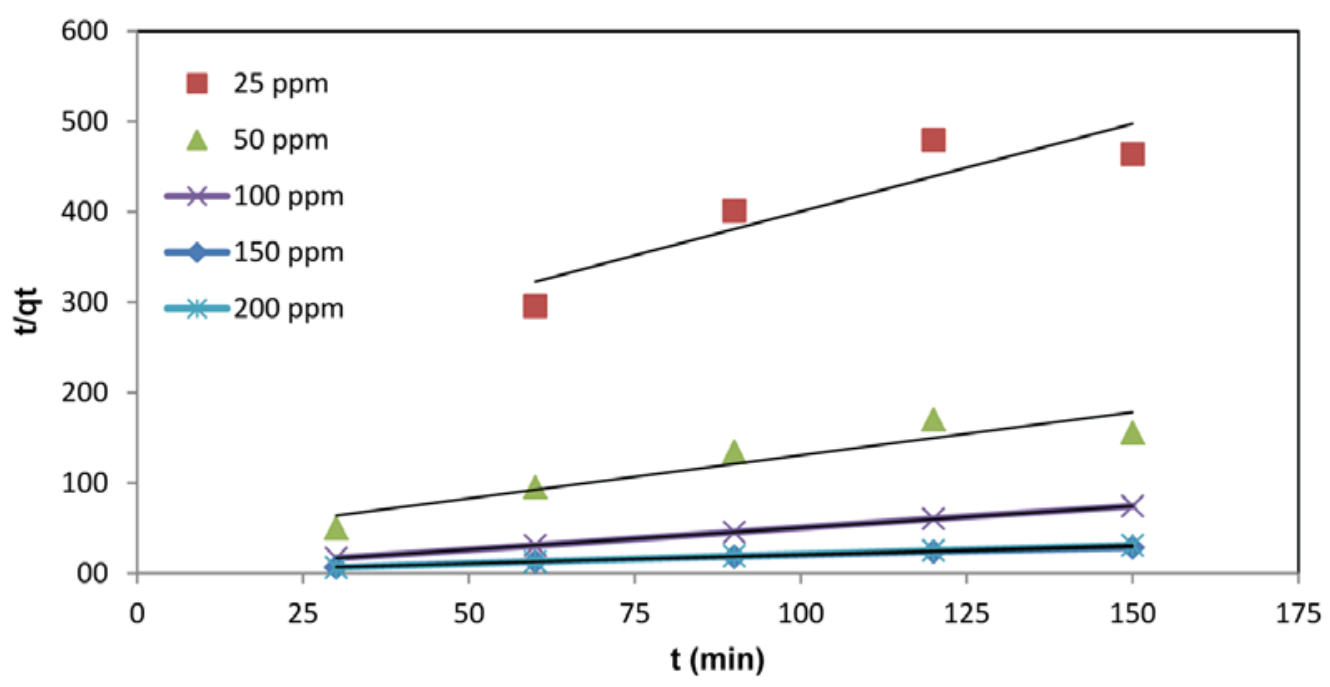

Figure 5. Pseudo-second -order plots at different initial 2.4 DCP concentrations (pH: 2; biomass: $1 \mathrm{~g}$, temperature $20 \pm 0.5$, agitation rate: $125 \mathrm{rpm}$ )

adsorbate and adsorbent systems although the process of the Pseudo-second-order kinetic model demonstrates chemisorptions which control the adsorption such as Vander Waals, hydrogen bonding, ion exchange etc. ${ }^{40}$ The process of 2,4- DCP adsorption in sweetgum bark may be chemisorptions. It is possible to see similar adsorbent performance for each of the three plots in initial concentrations 100, 150 and $200 \mathrm{ppm}$ when they are compared with each other's in Pseudo-second-order plots. However, $\mathrm{R}^{2}$ values are different. The maximum $\mathrm{R}^{2}$ value is found at $150 \mathrm{ppm}$ (Table 3, Figure 5). Also, it is possible to say the sorption system reached the final equilibrium plateau after $100 \mathrm{~min}$ and it started desorption after 150 minutes for initial concentrations 100, 150 and 200 ppm (Figure 3). This situation may demonstrate that there are surface binding sites on the biomass for the biosortion of 2,4-DCP and a number of biosorption mechanisms that included many factors such as physico-chemical adsorption, complexation, ion-exchange and micro-precipitation.

\section{5. Adsorption Isotherm Models}

Adsorption isotherm models are important in order to describe the sorption process. The data of adsorption isotherm models are also important to predict the adsorption capacity and describe the surface properties and affinity of the adsorbent. ${ }^{22}$ Two adsorption isotherm models were used to studies in the present study: the Langmuir isotherm model and Freundlich isotherm model. The general Langmuir equation whose linearized form is given as follows:

$$
C e / q e=1 / Q m . b+1 / Q m . C e
$$

where $\mathrm{C}_{\mathrm{e}}$ is the equilibrium concentration of the adsorbate $(\mathrm{mg} / \mathrm{L}), \mathrm{q}_{\mathrm{e}}$ is the amount of the adsorbate adsorbed per unit mass of the adsorbent ( $\mathrm{mg} / \mathrm{g})$, $\mathrm{b}$ is the Langmuir adsorption constant $(\mathrm{L} / \mathrm{mg})$, and $\mathrm{Q}_{\mathrm{m}}$ is the maximum adsorption amount $(\mathrm{mg} / \mathrm{g})$. $Q m$ and $\mathrm{b}$ can be determined from the linear plot of $C$ e/qe versus $C \mathrm{e}^{1,22}$

The dimensionless separation factor or equilibrium constant $\left(\mathrm{R}_{\mathrm{L}}\right)$ describes the essential characteristics of Langmuir isotherm. $\mathrm{R}_{\mathrm{L}}$ is defined as;

$$
\mathrm{R}_{\mathrm{L}}=1 / 1+b . C o
$$

where $\mathrm{Co}$ is the initial concentration $(\mathrm{mg} / \mathrm{I})$, and $\mathrm{b}$ is the Langmuir constant. Table 4 indicates dimensionless separation factor.

The Freundlich isotherm is an empirical relationship that describes the sorption on a heterogeneous surface. It can be linearized in logarithmic form as follows:

$$
\log q e=1 / n \log C e+\log K f
$$

where $\mathrm{C}_{\mathrm{e}}$ is the equilibrium concentration of the adsorbate $(\mathrm{mg} / \mathrm{L}), \mathrm{q}_{\mathrm{e}}$ is the amount of the adsorbate adsorbed per unit mass of the adsorbent $(\mathrm{mg} / \mathrm{g}), K_{\mathrm{f}}$ and $n$ are the Freundlich constants, whereas $K_{\mathrm{f}}$ and $n$ are indicators of adsorption capacity and adsorption intensity of the sorbents, respectively. ${ }^{18}$

The regression correlation coefficients $\left(\mathrm{R}^{2}\right)$ values of Freundlich isotherm model and Langmuir isotherm

Table 4. The dimensionless separation factor. ${ }^{39}$

\begin{tabular}{llllll}
\hline $\mathbf{R}_{\mathbf{L}}$ & $>\mathbf{1}$ & $\mathbf{= 1}$ & $\mathbf{0}<\mathbf{R}_{\mathbf{L}}<\mathbf{1}$ & $\mathbf{= 0}$ & $\mathbf{0 . 0 0 0 1 ( T h i s ~ s t u d y )}$ \\
\hline Sorption & unfavourable & linear & favourable & irreversible & irreversible \\
\hline
\end{tabular}


Table 5. Adsorption isotherm constants for 2.4-DCP onto sweetgum bark

\begin{tabular}{lcccccc}
\hline Phenol & $\mathbf{Q}_{\mathbf{m}}$ & $\begin{array}{c}\text { Langmuir model } \\
\mathbf{b}\end{array}$ & $\mathbf{R}^{\mathbf{2}}$ & $\mathbf{K}_{\mathbf{f}}$ & $\mathbf{n}$ & $\mathbf{R}^{\mathbf{2}}$ \\
\hline $2,4-\mathrm{DCP}$ & 8,176 & 52,36 & 0,9898 & 0,0077 & 0,722 & 0,9989 \\
\hline
\end{tabular}

model for initial concentration $(150 \mathrm{mg} / \mathrm{L})$ of $2,4-\mathrm{DCP}$ are 0.9989 and 0.9898 , respectively (Table 4), suggesting that the Freundlich isotherm model provided the best fit and Freundlich isotherm model exhibited a slightly better fit to the biosrption data of 2,4- DCP onto sweetgum bark than the Langmuir isotherm model in the initial concentration $(150 \mathrm{mg} /)$.

The adsorption equilibrium of heavy metals on various types of adsorbent was described by Freundlich isotherm and Langmuir isotherm models. However, the descriptions of adsorption equilibrium of organic pollutants such as phenol and chlorophenols were used the Freundlich isotherm model better than Langmuir isotherm model. ${ }^{1}$

The magnitude of $\mathrm{Q}_{\mathrm{m}}(8,176)$ for Langmuir isotherm model shows the amount of 2,4-DCP per unit weight of sorbent to form complete monolayer on the surface of a sample. Langmuir isotherm model was chosen, because of physical meaning of adsorption capacity $\left(\mathrm{Q}_{\mathrm{m}}\right){ }^{41}$

The value of adsorption capacity $\left(\mathrm{Q}_{\mathrm{m}}\right)$ for 2,4-DCP in present study was compared with the adsorption capacity of different adsorbents for 2,4-DCP (Table 6).

According to the equation (5), the value of $R_{L}$ is 0.0001 . This value indicates that sorption of 2,4-DCP on sweetgum bark may be irreversible. On the other hand, a value of correlation coefficient $\left(\mathrm{R}^{2}\right)$ for initial concentration of $150 \mathrm{mg} / \mathrm{L} 2,4-\mathrm{DCP}$ in Langmiur isotherm model is 0.9898 . This value indicates that there is a good agreement between the parameters and confirms the monolayer adsorption of 2,4-DCP onto sweetgum bark (Table 4).

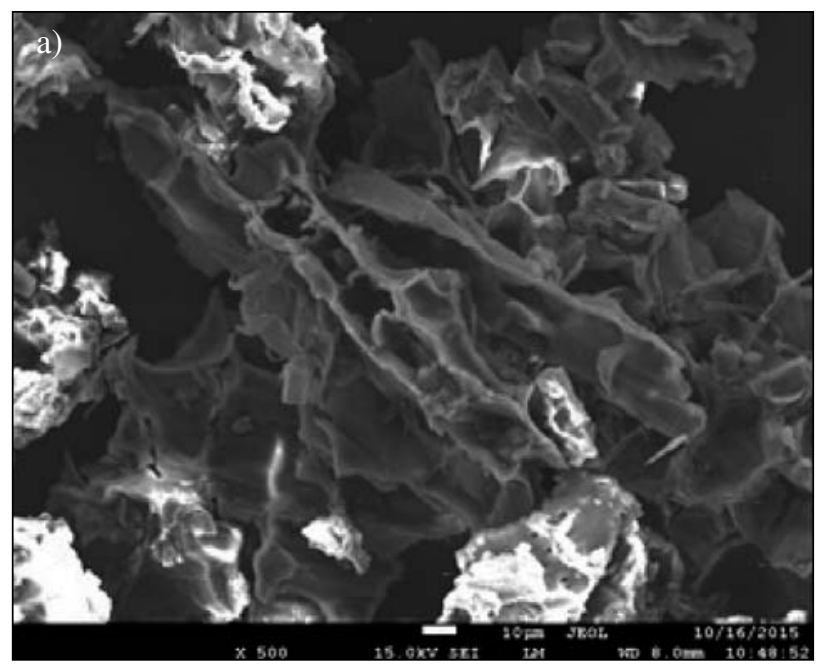

Table 6. Comparison of adsorption capacity for 2,4-DCP between sweetgum bark and other various adsorbents reported in the literature.

\begin{tabular}{lcl}
\hline Adsorbent & $\mathbf{Q}_{\mathbf{m}}(\mathbf{m g} / \mathbf{g})$ & Reference \\
\hline P.ocenica fibers & 1,11 & Demirak et al., 2011 \\
Rice Husk & 40,5 & Vadivelan et al., 2005 \\
Fly ask & 5,57 & Kumar et al., 2005 \\
Mycelial pellets & 4,09 & Wu and Yu., 2006 \\
Papermill sludge & 4,49 & Calace et al., 2002 \\
Sweetgum brk & 8.176 & This study \\
\hline
\end{tabular}

The constant values calculated from the Freundlich model for the biosorption equilibrium are given in Table 4. The values of $\mathrm{n}$ in this study are less than 1 , a favorable adsorption is indicated and chemical rather than physical adsorption is dominant.

In most cases, the kinetic parameters and the equilibrium parameters show good performance in batch. ${ }^{45}$ Previous studies show that the models are sensitive to sorption kinetic constants and to the mass transfer coefficient within the biosorbent. ${ }^{14}$ Adsorption models showed generally good performance, fitting the experimental data well in this study.

\section{6. Surface Characterization}

\section{6. 1. SEM Analysis}

SEM was used to observe the surface morphology of sweetgum bark samples and it is shown in Figure 6. SEM

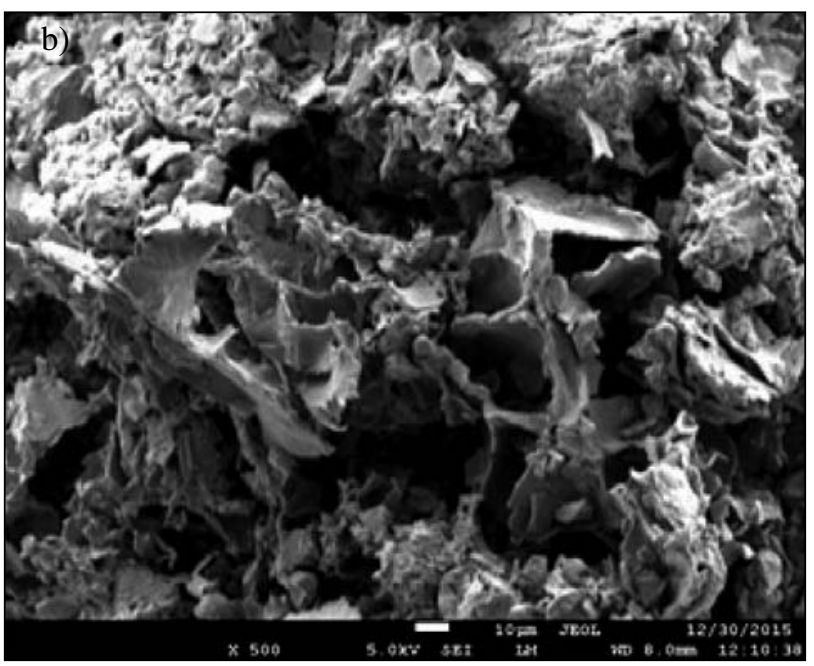

Figure 6. SEM pictures of sweetgum bark samples a) before the sorption of 2,4-DCP b) after the sorption of 2,4-DCP 
micrographs were taken at $1 \mathrm{kV}$ accelerating voltage and magnification was fixed according to $\times 1000$. The SEM micrographs show that it was obtained to different from the morphology of the samples. There is clear indicator of sorption of 2,4-DCP on dried sweetgum bark in SEM pictures.

\section{6. 2. FTIR Analysis}

FTIR spectroscopy of the extracts showed that the polar extractive spectra were consistent with the hydrolysabletannin compounds isolated during extractions of sweetgum bark. ${ }^{36}$ At the center of a hydrolyzabletannin, there is a . Phenolic groups were used to partially or totally esterify the hydroxyl groups of the carbohydrate. ${ }^{46}$ The information on the nature of the bonds on biomasses surface allowing the determination of different functional groups is offered by FTIR.
Figure 7 shows the changes of FTIR peaks for raw sweetgum bark compared to those after biosorption with 2,4-DCP Several peaks were observed from the spectra and this indicates that sweetgum bark is composed of various functional groups (Table 6).

In the spectra a new band is observed at $1708 \mathrm{~cm}^{-1}$, which can be assigned to ester formation. This peak indicates that he hydroxyl groups of the carbohydrate in sweetgum bark are with 2,4-DCP. These may be because of the interaction between the functional groups of sweetgum bark with 2,4-DCP compounds during the adsorption process.

\section{7. The Determination of $\mathrm{pHpzc}$} 5.68 .

Table 7. The FTIR spectral characteristics of sweetgum bark before and after biosorption of 2,4-DCP

\begin{tabular}{lcccl}
\hline $\begin{array}{l}\text { Wavelength } \\
\text { Range }\left(\mathbf{c m}^{-\mathbf{1}}\right)\end{array}$ & $\begin{array}{c}\text { Before } \\
\text { Biosorp. }\end{array}$ & $\begin{array}{c}\text { After } \\
\text { Biosorp. }\end{array}$ & Differences & Assignment \\
\hline $3500-3200$ & 3447 & 3423 & 24 & Bonded hydroxyl groups (phenolic OH and aliphatic OH \\
$1705-1715$ & & 1711 & New peak & C=O stretching (unconjugated ketone, carbonyl and ester groups \\
$1670-1500$ & 1635 & 1623 & 12 & Carboxylic groups \\
$1450-1375$ & 1454 & 1452 & 2 & Symmetric bending of CH3 \\
$1300-1000$ & 1317 & 1371 & 0 & -SO3 stretching \\
& 1036 & 1036 & 0 & C-O-C stretching in ethers. \\
\hline
\end{tabular}
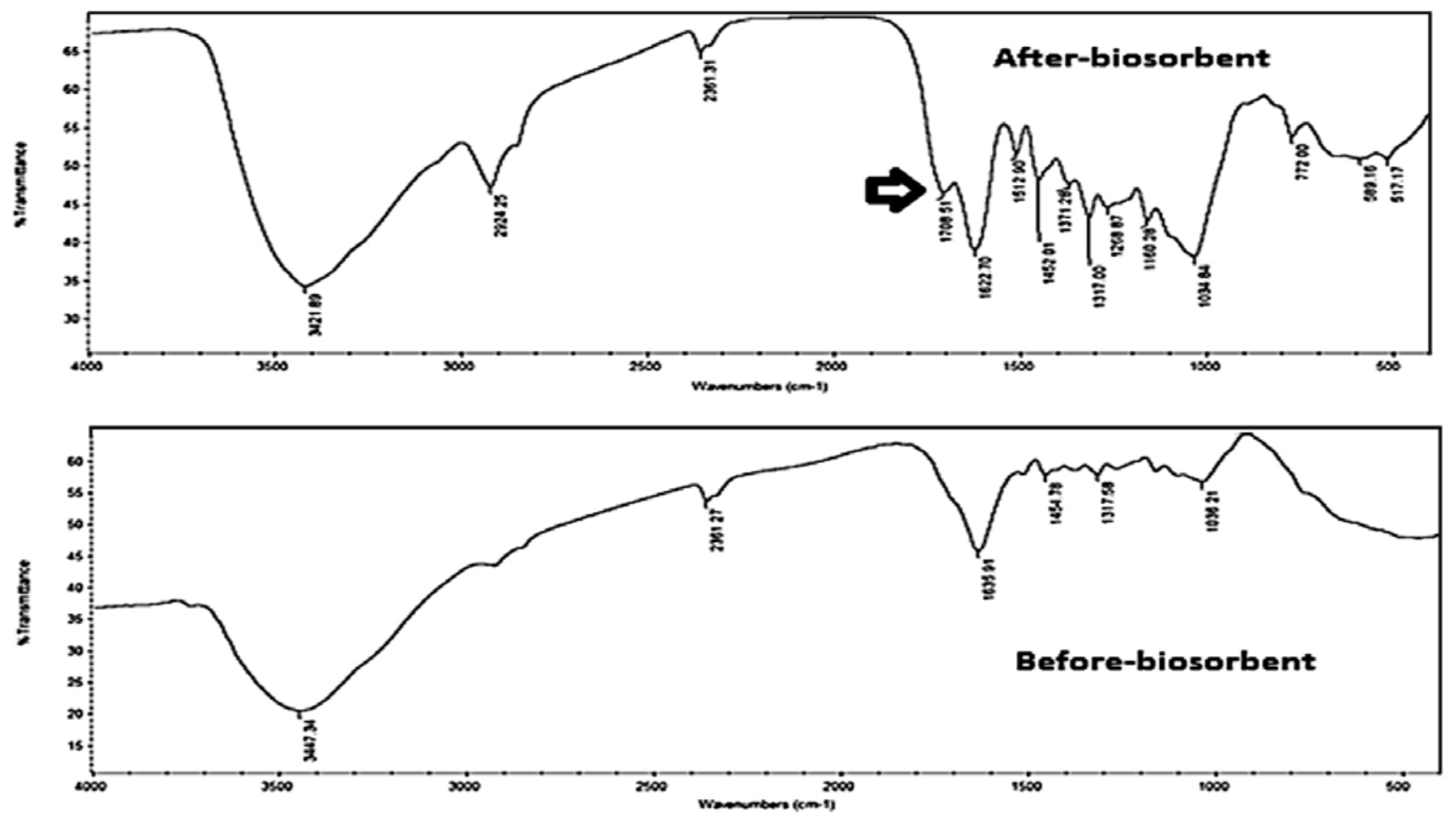

Figure 7. FTIR spectrum of biosorbent (before biosorption and after biosorption) 


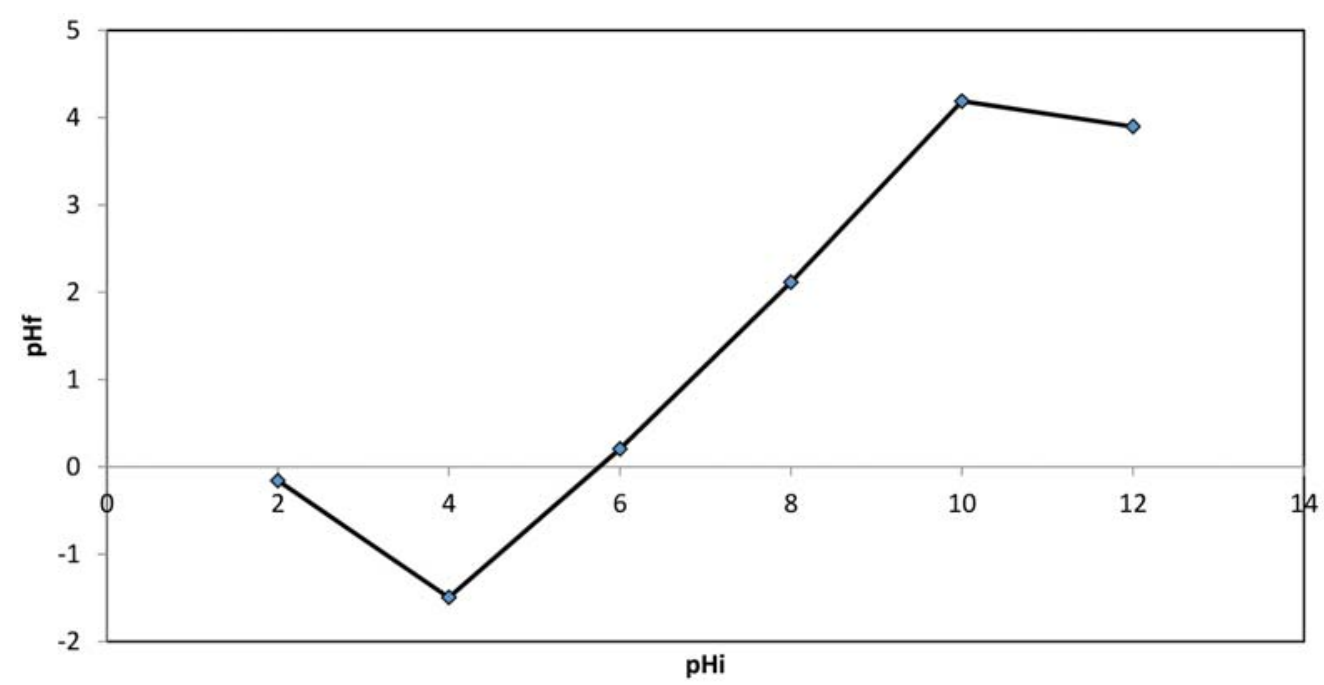

Figure 8. pHpzc value

\section{Conclusions}

- This study has been performed by using the Turkish sweetgum bark as a potent biosorbent for the removal of 2,4-DCP.

- The choice of the Turkish sweetgum bark was made according to some criteria, including its wastes that are left in the forest.

- The maximum adsorption capacity of 2, 4-DCP was observed at a $\mathrm{pH}$ of 2.0 .

- The rate of sorption capacities increased slightly at contact time of $150 \mathrm{~min}$.

- Taguchi's Orthogonal Array (OA) analysis was used to determine the values of optimum experimental parameters for adsorption capacity of 2,4-DCP onto Turkish sweetgum bark.

- The values of optimum experimental parameters for adsorption capacity of 2,4-DCP onto Turkish sweetgum bark can be explained clearly by Taguchi's Orthogonal Array (OA) analysis.

- Biosorption was determined by a Pseudo-second-order model predicting a chemisorption process.

- The equilibrium data were well characterized by the Langmuir isotherm model, which confirmed the monolayer coverage.

- The Freundlich isotherm model was found to represent the measured sorption data well.

- A new band is observed at $1708 \mathrm{~cm}^{-1}$ in FTIR, which can be assigned to ester formation. This peak indicate that hydroxyl groups of the carbohydrate in sweetgum bark are esterified with 2,4-DCP

\section{Acknowledgements}

This research was supported by Muğla Sitk1 Koçman University (Project no: 15/017)

\section{References}

1. W. Juan, Y. Han-Qing, J Hazard Mater B, 2006, 137, 498508. https://doi.org/10.1016/j.jhazmat.2006.02.026

2. N. S. Kumar, M. V. Subbaiah, A. S. Reddy, A. Krishnaiah, $J$ Chem Tech Biotechnol 2009, 84, 972-981. https://doi.org/10.1002/jctb.2120

3. V. C. Srivastava, M. M. Swamy, I. D. Mall, B. Prasad and I. M. Mishra, Colloid Surface A 2006, 272, 89-104.

4. S. P. Kamble, P. A. Mangrulkar, A. K. Bansiwal, S. S. Rayalu, Chem Eng J 2008, 138, 73-83. https://doi.org/10.1016/j.cej.2007.05.030

5. N. S. Kumar, K. Min, Chem Eng J 2011, 168, 562-571. https://doi.org/10.1016/j.cej.2011.01.023

6. A.Gholizadeh, M. Kermani, M. Gholami, M. Farzadkia, K. Yaghmaeian Asian J Chem 2013, 25, 7, 3871-3878.

7. A. Demirak, Ö. Dalman, E. Tilkan, D. Yıldız, E. Yavuz, C. Gökçe, Microchem. J 2011, 99, 97-102. https://doi.org/10.1016/j.microc.2011.04.002

8. A. S. Ghatbandhea, H. G. Jahagirdara, M. K. N. Yenkieb, and S. D. Deosarkarc, Russ J Phys Chem A 2013, 87, 8, 1362-1366.

9. M. W. Jung, K. H. Ahn, Y. Lee, K. P. Kim, Microchem. J. 2001, 70, 123-131. https://doi.org/10.1016/S0026-265X(01)00109-6

10. F. Kargi, S. Eker, Process Biochem 40, 6, 2005, 2105-2111.

11. E. Rubin, P. Rodriguez, R. Herrero, M. E. Sastre de Vicente $J$ Chem Tech Biotechnol 2006, 81, 1093-1099. https://doi.org/10.1002/jctb.1430

12. M. Akhtar, M. I. Bhanger, S. Iqbal, S. M. Hasany, J. Hazard. Mater. B 2006, 128, 44-52. https://doi.org/10.1016/j.jhazmat.2005.07.025

13. S. K. Nadavala, K. Swayampakula, V. M. Boddu, K. Abburi, J Hazard Mater 2009, 162, 482-489 https://doi.org/10.1016/j.jhazmat.2008.05.070

14. A.Kogej, B. Likozar, A. Pavko, Food Technol. Biotechnol, 2010, 48,3, 344-351. 
15. M. Sathishkumar, A. R. Binupriya, D. Kavitha, S.E. Yun, Bioresour. Technol. 2007, 98, 866-873. https://doi.org/10.1016/j.biortech.2006.03.002

16. M. Sathishkumar, K. Vijayaraghavan, A. R. Binupriya, A. M. Stephan, J. G. Chai, S. E. Yun, J Colloid Interface Sci. 2008, 320, 1, 22-29. https://doi.org/10.1016/j.jcis.2007.12.011

17. M. Sathishkumar, A. R. Binupriya, D. Kavitha, R. Selvakumar, R. Jayabalan, J. G. Choi, S. E. Yun, Chem. Eng. J. 2009, 147, 265-271. https://doi.org/10.1016/j.cej.2008.07.020

18. A. Bhatnagar, A. K. Minocha, J. Hazard. Mater. 2009, 168, 1111-1117. https://doi.org/10.1016/j.jhazmat.2009.02.151

19. N. Unlu, M. Ersöz, J Hazard Mater, 2006, 136, 272-280. https://doi.org/10.1016/j.jhazmat.2005.12.013

20. A. Sarı, M. Tüzen, D. Çıtak, M. Soylak, J Hazard Mater, 2007, 148, 387-394. https://doi.org/10.1016/j.jhazmat.2007.02.052

21. S. Tunalı, T. Akar, A. S. Özcan, İ. Kıran, A. Özcan, Separ Purif Method, 2006, 47, 105-112. https://doi.org/10.1016/j.seppur.2005.06.009

22. L. Wang, J. Zhang, R. Zhao, C. Zhang, C. Li, Y. Li, Desalination 2011, 266, 175-181. https://doi.org/10.1016/j.desal.2010.08.022

23. A. Gholizadeh, M. Kermani, M. Gholami and M. Farzadkia, J. Environ. Health Sci. Eng. 2013 DOI: 10.1186/2052-336X11-29 https://doi.org/10.1186/2052-336X-11-29

24. I. Gurbuz, E. Yesilada, B. Demirci, E. Sezik, F. Demirci, K. H. Baser, J Ethnopharmacol 2013, 148, 332-336. https://doi.org/10.1016/j.jep.2013.03.071

25. Standard Methods for the examination of water and wastewater, Washington, D. C.: APHA-AWWA-WEF, 2005.

26. Y. S. Lee, J. Kim, S. G. Lee, E. Oh, S. C. Shin, I. Park, 2009, Pestic Biochem Physiol, 93, 138-143. https://doi.org/10.1016/j.pestbp.2009.02.002

27. M. Mahmoodian, A. B. Arya, B. Pourabbas, Dent. Mater. 2008, 24, 514-521. https://doi.org/10.1016/j.dental.2007.03.011

28. G. Taguchi, Y. Yokoyama, Y. Wu, American Supplier Institute (ASI) Press, Tokyo 1993.
29. S. H. Park, Robust Design and Analysis for Quality Engineering, Chapman \& Hall, London 1996.

30. D. R. Cox, N. Reid, Chapman \& Hall/CRC, London 2000.

31. C. Douglas, Montgomery, Design and Analysis of Experiments, Wiley, New York 2001.

32. R. Torkaman, M. Soltanieh, H. Kazemian, Chem. Eng. Technol. 2010, 33, 902-910. https://doi.org/10.1002/ceat.200900367

33. R. Roy, A Primer on the Taguchi Method, Van Nostrand Reinhold, New York 1990.

34. H. Zaghouane-Boudiaf, M. Boutahala, Chem Eng J, 2011, 170, 120-126. https://doi.org/10.1016/j.cej.2011.03.039

35. Z. Aksu, J. Yener, A Waste Manag. 2001, 19, 674-677.

36. L. Thomas, N. L. Eberhardt, C. L. Seok. Kim, K. G. Reed, D. J. Leduc, J. M. Warren, Trees, 2015, 29, 1735-1747.

37. F. A. Banat, B. Al-Bashir, S. Al-Asheh, O. Hayajneh, Environ. Pollut 2000, 107, 3, 391-398. https://doi.org/10.1016/S0269-7491(99)00173-6

38. Z. Aksu, D. Akpinar, Separation Purif. Technol. 2000, 21, 87-99. https://doi.org/10.1016/S1383-5866(00)00194-5

39. Z. Aksu, Separation Purif Technol. 2001, 21,3, 285-294. https://doi.org/10.1016/S1383-5866(00)00212-4

40. S Kuppusamy, T Palanisami, M Megharaj, K Venkateswarlu, R Naidu Rev Environ Contam T, 2016, 236, 117-192.

41. B. Likozar, D. Senica, A. Pavko, Braz. J. Chem. Eng, 2012, 29, 635-652Z. https://doi.org/10.1590/S0104-66322012000300020

42. Z. Chen, H. Deng, C. Chen, Y. Yang, H. Xu, J. Environ. Health Sci. Eng. 2014, 12, 63, 1-10.

43. V. Vadivelan, K. Kumar, J. Colloid Interf. Sci. 2005, 286, 90-100. https://doi.org/10.1016/j.jcis.2005.01.007

44. K.V. Kumar, V. Ramamurthi, S. Sivanesan, J. Colloid Interf. Sci. 2005, 284, 14-21. https://doi.org/10.1016/j.jcis.2004.09.063

45. B. Likozar, D. Senica, A. Pavko, AIChE, 2012,58, 99-106. https://doi.org/10.1002/aic.12559

46. N. Calace, E. Nardi, B. M. Petronio, M. Pietroleytti, Environ. Pollut. 2002, 118, 315-319. https://doi.org/10.1016/S0269-7491(01)00303-7

\section{Povzetek}

Proučevane so bile lastnosti odpadnega lesa turškega ambrovca (Liquidambar styraciflua) kot biosorbenta za 2,4 diklorofenol $(2,4-\mathrm{DCP})$ iz vodne raztopine. V šaržnih eksperimentih pri $25^{\circ} \mathrm{C}$ so bili raziskani vplivi pH-ja kontaktnega časa, začetne koncentracije 2,4-DCP in množine biosorbenta. Za optimiranje procesa je bila uporabljena Taguchijeva ortogonalna metoda. Lastnosti biosorbenta so bile analizirane s pomočjo FTIR in SEM tehnik. Eksperimentalni podatki so bili obdelani z Langmuirjevim in Freundlichovim modelom adsorpcijskih izoterm. Rezultati potrjujejo enoplastno adsorpcijo. Kinetične študije kažejo, da je za opis tega sistema primeren model pseudo drugega reda. 